\title{
INTERDISCIPLINARY TUTORING FOR THE DEVELOPMENT OF PROFESSIONAL-SIMULATION ROLE-PLAYS
}

Cristina Castillo-Rodríguez¹: Universidad de Málaga. España ccastillor@uma.es

Deborah García-Magna: Universidad de Málaga. España dgmagna@uma.es

Sonia Ríos-Moyano: Universidad de Málaga. España srios@uma.es

Carmen Cristófol-Rodríguez: Universidad de Málaga. España carcrir@uma.es

Rosa Rodríguez-Mérida: Universidad de Málaga. España rmrodriguez@uma.es

María Jesús Carrasco-Santos: Universidad de Málaga. España mjcarrasco@uma.es

\begin{abstract}
\footnotetext{
${ }^{1}$ Autor correspondiente

Cristina Castillo-Rodríguez: Universidad de Málaga. España

Correo: ccastillor@uma.es
}

Current society is characterised by a growing tendency of interrelationship among different professional sectors in order to offer their potential customers a better quality of certain products or process. Thereby, and in the context of this interdisciplinarity, higher-education teachers must frame their teaching methodologies mainly focused on the acquisition of certain competences so that students could guarantee the development of their professional abilities. Taking this as a premise, we have performed an interdisciplinary role-play so as to allow our students to acquire those professional competences. However, to carry out this performance a well-organised tutorial plan, divided into several tutoring sessions, 
was required to succeed in the use of this active methodology.

KEY WORDS: Interdisciplinarity - Active methodology - Role-play - ProfessionalSimulation - Tutoring

\section{TUTORIZACIÓN INTERDISCIPLINAR PARA EL DESARROLLO DE JUEGOS DE SIMULACIÓN PROFESIONAL}

\section{RESUMEN}

La sociedad actual se caracteriza por la creciente tendencia de los profesionales de distintos sectores a interrelacionarse entre sí para así ofrecer una mejor calidad de determinados productos o procesos a los potenciales clientes. De esta forma, y en el contexto de esta interdisciplinariedad, los profesores universitarios deben encuadrar sus metodologías docentes fundamentalmente centradas en la adquisición de determinadas competencias para garantizar a los estudiantes el desarrollo de sus habilidades profesionales. De esta forma, hemos llevado a cabo un juego de rol interdisciplinar para así permitir a nuestros estudiantes que adquieran esas competencias profesionales. Sin embargo, para poder realizar esto ha sido necesario organizar un buen plan tutorial, dividido en varias sesiones de tutorías, con el fin de sacar un mejor provecho de esta metodología activa.

PALABRAS CLAVE: Interdisciplinariedad - Metodología activa - Juego de rol Simulación profesional - Tutorización

\section{INTRODUCTION}

All of us are aware of the relevance in our society of collaboration among professionals belonging to different knowledge fields. We only have to observe each one of the job positions from different enterprises so as to realise that these different professionals do not carry out their work independently, and by applying all the knowledge acquired in their degrees at the university. Reality reveals us that they must interact with other professionals from different specialised fields, since all of them set up the wheels of a machine which are essential so that this machine, and therefore, the product and/or process, can obtain the highest quality for their customers' satisfaction. 
We, as teachers, must be aware of this reality, since today, apart from the specific abilities of every discipline, students must acquire other cross-curricular competences in order to complete their formation and to manage to interact with all the professionals of labour market. Thus, in García Magna et al. (2011), we took into account this reality when we began with our educational innovation project, which was carried out in two academic years, that is 2009-2010 and 2010-2011, and we proposed a template for the design of interdisciplinary role-plays. This template contains a series of variables that every teacher should have to take into account for the perfect development of his/her interdisciplinary role-play. Therefore, one of the key elements, or variables, of this methodology is students' tutoring, whose main purpose consists not only of explaining each one of the phases of the role-play itself, the roles, functions and aims of the play, but also of solving all the doubts arising during the performance of the role-play.

In fact, the purpose of this article is to highlight the main aspects related to the tutorial action carried out in an interdisciplinary role-play celebrated in the academic year 2010-2011, and in which the main topic was The Carnival party in Malaga. Students participating in this empirical experiment obtained a voluntary agreement and signed an informed consent. These participants belonged to the disciplines of Translation and Interpreting, Audiovisual Communication, Fine Arts, History of Art and Marketing and market research.

Before explaining the tutorial sessions of this role-play, it is necessary to point out the importance that the concept of interdisciplinarity has acquired in the new university academic context promoted by the European Higher Education Area (EHEA), as well as the duality between face-to-face tutoring of our old university system (which is still in force, although partially since new degrees are occupying the whole university context) and the new conception of virtual tutoring in which we can include other virtual ways of communication (with obvious space and time advantages) between the teacher and the student, which is commonly called "virtual tutoring" since it uses web environment as its main support.

\section{CONTRIBUTIONS}

\subsection{The importance of interdisciplinary learning in the new context of}

\section{Higher Education}

Plans of the different degrees had been focused, so far, on the theoretical knowledge of each discipline, in spite of the fact that in the future students will probably have to develop a specific work in a field composed by different experts from other areas. However, from the establishment of the new EHEA, other competences are also taken into account, apart from the cognitive competences that traditionally have been considered the most important ones when teaching a specialised subject. We refer to 
decision making and solving problems, working in a collaborative environment, developing a strategic thought, or even the ability of being involved in a specific area of a certain enterprise, being critical, among others.

Due to the fact that new plans and syllabus have been adapted, professional training based on competences has become important, apart from the concepts of interdisciplinarity and independent learning (or self-learning) of the student, as Posada Álvarez (Posada Álvarez, 2004) points out. In fact, in order to develop the professional competences, aspects such as organizational abilities and collaborative work must be considered, because they are essential for setting up multifunctional teams. These teams must be able to carry out and develop the foundational objectives of the organisations in which they are involved.

As we have mentioned before, professional careers cannot be performed separately, because they are performed in a labour space in which professionals from different knowledge fields are included. Thereby, in the frame of an enterprise, economists, clerks, lawyers, psychologists in charge of a human resources department, translators, interprets, etc. can "live" and work together. That is the reason why it is very important to prepare our students so that they can work with other professionals when they finish their academic degrees.

These competences cannot be only acquired with collaborative learning in a given area, or through its theoretical concepts. We need to go beyond the conventional methods and to make different disciplines converge until our students are ready for their future careers. That is why it is very important for our students to acquire the competences we have mentioned before, since our students will be required to learn how the rest of the professionals with whom they will collaborate in the future work in their fields.

The collaborative learning, above all if this is carried out in an interdisciplinary context, makes that our students acquire and develop most of these competences; however, it is necessary for us, as teachers, to follow good and well-planned tutoring sessions.

\subsection{Virtual tutoring as a new modality of tutorial action}

Searching for a high-quality education is one of the key aims of the new EHEA. In this search, supported in the development of new ways of teaching-learning and in a model based essentially on the participation of our learners, a good Tutorial Action Plan $^{2}$ (TAP) is shaping up, in our opinion, as a highly relevant tool for a satisfactory performance of our learners or students at both personal and professional levels. 
Flexibility must constitute a key element in the new system. In this sense, we consider that the setting up and the subsequent performance of a suitable TAP are very important for the improvement of the quality of our university, since it favours, among other aspects, a better incorporation and adjustment to the university system, the development of the professional career, the continuous training and the transition period until reaching the labour market.

In the frame of this context, we believe that the TAP is one of the tools that, in our opinion, can constitute an interesting possibility for working with our students in this new university system.

Nevertheless, one of the matters that is unresolved of the higher education is the scarce contact between teachers and students. We accept the hypothesis that learning at the university requires, apart from a teaching action of the teacher himself/herself, a guiding intervention leading our students' learning in such a way that teaching and guidance of the learning process could constitute the two essential requirements of a good teacher. It is necessary to distinguish between the academic functions limited to prepare the student to succeed in passing their subjects and modules - stressing the learning process itself - and the personal advising functions guiding the student in all those matters relevant with regard to his/her relationship with the university.

The introduction of compulsory tutoring sessions as one of the teacher's tasks has been a great advance, since it has allowed students to know the availability of the teachers and to know where and when attend them so as to complement their formation, to solve their doubts or to ask for more material or information. Even though in theory tutoring sessions have a guiding and self-assessment role, the reality is very different. Tutoring sessions are usually the last resource for the student, who actually loses the opportunity of taking advantage of a rich training complement throughout the whole period of the subject or module. Therefore, it is our duty, as teachers, to promote and enhance the use of tutoring sessions as suitable resources so as to avoid, largely, one of the main problems of higher education: the absence or the lack of a good university guidance enabling the student in his/her learning acquisition and in his/her subsequent work placement.

Most of the situations of our students at university, such as giving up their studies, longer period for their studies, the scarce participation in university activities, the ignorance of their rights, the difficulties found to face the change, etc., makes the tutoring session a perfect space for the achievement of an effective learning, due to the fact that it allows us to follow and guide our students and carry out a customised guidance according to the needs and requirements of every student. 
Therefore, the TAP must define and control the actions devoted to achieve a complete integration of the students inside the university context, as well as the elements that make it easier their own educational decisions, and to enhance a closer relationship between teachers and students, among others. Likewise, it can have different formats, but, at least, it has to include the aims, goals and criteria that the actions to be carried out will have to fulfill.

However, the acceptance of a tutoring model supposes a great challenge. There are different types of tutoring, such as the model of a comprehensive tutoring proposed by Arbizu (Arbizu et al., 2005), who boost a comprehensive development of the student from different sides, both academic and professional, as well as emotional and personal. Although it is very interesting, this plan demands a great effort of all the teachers, since it requires them a great commitment and training in guidance actions.

\subsection{Teacher-student relationship in face-to-face tutoring sessions}

During the years in force of the old Spanish Law of University Reform, commonly known as LRU ${ }^{3}$, face-to-face tutoring was conceived as an optional space for students although a compulsory duty for teachers. The main purpose of these tutoring sessions was the solution of punctual problems (by definition, they were entirely academic but they used to become personal) rather than a learning assessment, or controlling their training or formation or as an aid for the development of certain competences (as they are now conceived in the EHEA).

The traditional approach of the tutoring sessions implied for teachers a work of professional guidance, academic and even "psychological". For students, however, these sessions were considered as an additional time for solving their procedural doubts of certain subjects, of the academic institution or of their professional future. They were utterly voluntary: teachers used to expect their students in a reactive situation, since the decision of attending these sessions fell on the students' interest.

This relationship also implied for teachers, due to the ignorance of their students' demands, to be in an expecting situation which occasionally led them to have a confusion attitude when the students exposed them their doubts.

Therefore, we can state that students have not considered face-to-face tutoring sessions as an additional element for their learning process. This together with the distance existing between both teachers and students, due to the excesive number of students per group, had as a consequence the fact that nobody attended this academic activity.

3 This abbreviation stands for Ley de Reforma Universitaria, whose legislation is regulated by the Organic

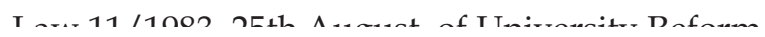


The lack of interest was also caused by the ignorance of their purpose: students did not find an immediate and pragmatic utility when attending a tutoring session, and teachers did not know how to motivate them to participate actively in those sessions. For students, the main aim of face-to-face tutoring sessions has been to clarify the process by means of which they could pass a subject/module. Besides, their attendance has also depended on the type of subject taught, its difficulty, teachers' accessibility, timetable compatibility with the rest of the subjects, etc., which has determined a non-existent relationship between teachers and students.

\subsection{The advantages of virtual environment for tutoring sessions}

Today, and after more than fifteen years working with the Net, we have witnessed a progressive introduction of Internet in our professional lives. Even though in the midnineties there were more detractors than supporters, step by step the resources and utilities of Internet era have revolutionised one of the distinguishing characteristics of the university. We have also witnessed a change with regard to the direct treatment in the academic context, towards other spaces allowing a greater space and time freedom, both for teachers and for students, which widens the ways of communication and, therefore, the ways for teaching-learning and guidance.

The platforms which are available in the frame of the university context make it easier the development of tutoring actions, breaking the barriers of the classical timetables of face-to-face tutoring sessions. Moreover, teachers have learnt how to incorporate this new modality of tutoring action to their daily teaching profession, since, in spite of the fact that it demands an additional work to their tutoring sessions, it sometimes allows them a better organisation of the questions and/or doubts due to a better work of documentation and research of the specific questions expressed by their students.

The types of virtual tutoring that, in our opinion, are more beneficial for a better solution of certain problems are, on the one hand, the one carried out by means of the use of the electronic mail (e-mails), and, on the other hand, all those actions carried out by using the resources and tools enabled by the educational platforms in a web environment, since these ones, besides, allow the creation of other spaces (private or public) for working in the frame of the academic context.

One of the most used platforms in the educational field is the well-known Moodle, since it has a clear and intuitive interface; however, today, there are other online applications such as web 2.0, which are used with the same guarantees of quality for virtual tutoring sessions.

We estimate that the one that gives us more benefits is, undoubtedly, the use of tools of the educational platforms. Among tools gathered in these platforms, the most popular and easiest to use is the so called "forum", by means of which students are 
resources of the web 2.0. Nevertheless, these educational platforms allow students to participate actively in their own learning process, by using correctly the specific terminology of their discipline and looking after their own written expression.

Thereby, teachers can control what they want to highlight or intensify in the learning of their own students, as the questions related to certain doubts requiring to be clarified are written, allowing other students to consult them or to investigate them more actively on the Net by adding links related to the topic they are concerned; so a collaborative learning is also enhanced.

\subsection{Interdisciplinary tutoring sessions for professional-simulation role- plays}

In the academic context of the university, active methodologies began to appear some years ago so as to promote the learning-teaching process and, above all, to enhance the collaborative learning among university teachers. Among active methodologies we can highlight the so called simulation techniques (Ruben, 1999), and, among the latter, the well-known role play or role playing.

The main aim of this type of simulation techniques is that each participant carries out a certain role in the context of a simulated real situation according to certain rules previously established and by interacting with other participants of the same simulation game (Castillo Rodríguez et al., 2011). Furthermore, this methodology provides plenty of benefits and advantages such as: the acquisition of cross-curricular competences, the promotion of the collaborative learning, and the interaction between teachers and students.

In spite of the fact that, as Armstrong (Armstrong, 2003) pointed out, in the university context there are no empirical studies regarding role plays, this simulation technique is one of the active methodologies that better emulates the professional context in which students will develop their work in the future. The weak point that this type of activities usually has is that they require teachers to spend time and effort for their organisation and practical application. Besides, if we add the interdisciplinarity component so that we can reflect the reality of the professional environment, we will find more difficulties. That is the reason why it is necessary to have certain clear guidelines allowing the teacher to succeed in the implementation of this teaching technique.

The interdisciplinary role play we carried out during the academic year 2010-2011 consisted mainly of the simulated execution of a press conference so as to present the Carnival poster of Malaga. The creation of teams to carry out this interdisciplinary simulation game was proposed: communication team, journalist team, marketing team, design and illustration team, design experts team, documentation and research team, art critics team, and interprets team. 
With the aim of performing a well organisation of the simulation game, we followed the variables contained in the template proposed by García Magna et al (2011). One of this variable is the tutoring sessions carried out for a correct development of the game itself.

Tutoring action becomes an essential element so that our students can take advantage of this interdisciplinary active methodology. As far as our case is concerned, we have carried out different types of tutoring, which have been followed in different sessions.

The first session of our tutoring action in this interdisciplinary role play consisted of an initial face-to-face tutoring session with the whole group participating in the simulation game, that is, all the teams as well as the teachers involved in it. In this first session, the rules of the role play and the practical situation that was going to be simulated were explained in detail. Besides, certain doubts regarding the general development of the activity were also exposed.

A second session of tutoring was carried out by means of virtual forums that is to say, we organised several virtual forums so that teachers of the degrees (or more concretely, the subjects involved in this role play) participating in the empirical experiment could solve the doubts of their own students about certain aspects of their subjects and to what extent these subjects had an influence on the game itself.

Afterwards, another face-to-face tutoring session was performed; that is, all the students involved in the interdisciplinary experiment had a meeting with their teachers but simultaneously in the same room, although they were separated according to their disciplines. To carry out this third tutoring session a bigger classroom was required.

The fourth session, which was developed after the previous one, consisted of 10-minutes interdisciplinary tutoring sessions with small groups of the students participating in the game. In this session, students were asked to take notes about their roles and the kind of interaction they will develop with other participants during the game itself. This way, we started an interdisciplinary professional pre-simulation game.

The next session of tutoring was completely virtual, in which, taking advantage of the space and time benefits of forum tool, both students and teachers felt free to organise the activities previously to the interdisciplinary role play. Thus, in the forums created for the second tutoring session the access to students from other disciplines was allowed. This way, we enhanced the creation of interdisciplinary debates in which all the previous tasks to be taken into account for the correct implementation of the interdisciplinary role play were explained. 
Finally, once they represented their role in the role play, another face-to-face tutoring session was carried out with the participation of all the students and teachers so as to solve certain doubts derived from the activity and to assess the development of the game as a whole.

\section{CONCLUSIONS}

There is no doubt that tutorial action plays a relevant role at the current university. The traditional way of conceiving the teaching process has supposed that tutoring sessions were considered as a period of time in which teachers were waiting for their students at their office in case they wanted to pose some doubts regarding the syllabus of a subject, the lessons or any other administrative problem. A new system based on an active self-learning of the students has obviously transformed the concept of tutoring session, requiring an active involvement of the participant actors of this process, that is, both teachers and students.

The aim of this paper has been to describe our own experience based on the use of the active methodology called role play, which has consisted of the simulation of a professional situation in an interdisciplinary context, with the participation of students and teachers belonging to different disciplines and knowledge fields. Although there are a lot of advantages when using this methodology, we must not forget that if we want to succeed in this kind of activities, a well-organised tutorial action must be taken into account. This way, we have considered essential to plan and carry out an exhaustive tutoring plan, divided into different tutoring sessions, in which we have mixed some face-to-face sessions and some virtual ones, and not only in groups of the same disciplines, but also performing some interdisciplinary tutoring sessions.

Although the performance of this type of methodologies has supposed a great effort for both the organisation and the performance of the game itself, we consider that the results that we have obtained have shown that this effort was necessary and essential because it has widely satisfied our expectations. 


\section{REFERENCES}

Arbizu, F., Lobato, C., Del Castillo, L. (2005). Algunos modelos de abordaje de la tutoría universitaria. Revista de Psicodidáctica, 1: 7-22.

Armstrong, E. K. (2003). Applications of Role Playing in Tourism Management teaching: Evaluation of a Learning Method. Journal of Hospitality, Leisure, Sport and Tourism Education, 2(1): 5-16.

Castillo Rodríguez, C., García Magna, D., Cristófol Rodríguez, C., Rodríguez Mérida R. \& Ríos Moyano (2011). Adquisición de competencias en un contexto interdisciplinar: el juego de rol como metodología innovadora. Trabajo presentado al Actas del VII Congreso Internacional sobre Educación, Cultura y Desarrollo (sin paginar). Málaga: Grupo de Investigación Eumed.net.

García Magna, D., Castillo Rodríguez, C., Ríos Moyano, S., Cristófol Rodríguez, C.; Carrasco Santos, M. J., Rodríguez Mérida, R., Pastor García, I, González Ramírez, D. (2011). La interdisciplinariedad en la educación superior: propuesta de una guía para el diseño de juegos de rol. Revista Teoría de la Educación: Educación y Cultura en la Sociedad de la Información, 12 (1). Recuperado el 6 de diciembre de 2011, de Disponible en http:/ / campus.usal.es/ revistas_trabajo/index.php/revistatesi/issue $\angle$ view/568

Junta De Andalucía. (1995). La Acción Tutorial. Sevilla: Consejería de Educación y Ciencia. Dirección General de Promoción y Evaluación Educativa.

Posada Álvarez, R. (2004). Formación superior basada en competencias, interdisciplinariedad y trabajo autónomo del estudiante. Revista Iberoamericana de Educación. Recuperado el 6 de diciembre de 2011, de

Disponible en http:/ / www.rieoei.org/deloslectores/648Posada.PDF

Ruben, B. D. (1999). Simulations, Games, and Experience Based Learning: The Quest for a New Paradigm for Teaching and Learning. Simulation and Gaming, 30 (4):498-505. 


\section{Cristina Castillo Rodríguez}

Se licenció en Traducción e Interpretación (inglés, francés, italiano) en el año 2003 por la Universidad de Málaga, donde también realizó sus cursos de doctorado en el bienio 2003-2005. En el año 2010 obtuvo el grado de doctor con mención de doctorado europeo con la tesis doctoral El trabajo terminográfico en traducción: explotación de un corpus multilingüe de turismo de salud y belleza (español-francés/inglés/italiano). Actualmente, es profesora en el grado de Estudios Ingleses en el departamento de Filología Inglesa, Francesa y Alemana de la Universidad de Málaga y Profesora Adjunta en la Universidad Internacional de La Rioja.

\section{Deborah García Magna}

Profesora Colaboradora de Derecho Penal en la Facultad de Derecho de la Universidad de Málaga y Profesora-Investigadora en el Instituto Andaluz Interuniversitario de Criminología (Sección de Málaga). Desde el año 2001, ha impartido clases de Derecho penal, en la Licenciatura y el Grado en Derecho y en el Título de Experto en Criminalidad y Seguridad Pública, y de Derecho penal y Derecho procesal penal en el Título de experto en Psicología Forense, además de participar como ponente en varios congresos de Criminología y un curso de verano sobre patrimonio arqueológico subacuático.

\section{Sonia Ríos Moyano}

Doctora en Historia del Arte por la Universidad de Málaga. Es miembro del Grupo de Investigación de la Junta de Andalucía HUM 130 y participa como investigadora en varios proyectos I+D. Es autora de varias investigaciones publicadas en libros, capítulos de libros, artículos y reseñas relacionadas con el diseño y la publicidad en revistas nacionales. Ha realizado más de 600 horas de formación docente en materias relacionadas con la convergencia, formación para la innovación y aplicaciones informáticas orientadas al aprendizaje de plataformas educativas y las TICs. Actualmente, es profesora contratada doctora en el departamento de Historia del Arte de la Universidad de Málaga.

\section{Carmen Cristófol Rodríguez}

Licenciada en Publicidad y RRPP (1997-2001) y Doctora por la Universidad de Málaga (2010). Entre 2005 y 2007 impartió la asignatura de Planificación de Medios en la Licenciatura de Publicidad y RR PP de EADE (Título otorgado por la Universidad de Gales). Desde 2008 imparte docencia en la Facultad de Ciencias de la Comunicación de Málaga, donde es profesora asociada. Además es Experta en Protocolo y Organización de eventos institucionales por la Universidad de Málaga, Máster en Gestión Comercial y Dirección de Marketing y Programa Superior de Dirección de Ventas por ESIC Marketing\& Business School. Miembro del Grupo “Nuevas formas publicitarias y nueva economía" (SEJ 396). 


\section{Rosa Rodríguez Mérida}

Doctora en Bellas Artes por la Universidad de Málaga (2011), actualmente es Profesora Asociada en la Facultad de Bellas Artes de la citada Universidad desde el año 2006. Coordinadora de las asignaturas de Procesos del Dibujo I y Procesos del Dibujo para el Diseño en Grado de Bellas Artes, imparte clase en dichas asignaturas junto con Proyectos II en la Licenciatura de Bellas Artes. Su actividad docente e investigadora, y a su participación en distintos congresos, cursos y talleres, desarrolla su actividad profesional como Directora Artística de distintas Colecciones Editoriales de ámbito nacional. Al igual que participa en exposiciones colectivas como artista plástica.

\section{María-Jesús Carrasco Santos}

Doctora con mención europea desde 2011 por la Universidad de Málaga. Actualmente, es Profesora Colaboradora con docencia en Marketing en la Universidad de Málaga. 